sowską i Alinę Grefkowicz (Warszawa 1995) w indeksie serii wydawniczych. Z pobieżnego tylko oglądu wynika, że w tym czasie publikowane były serie kierowane do konkretnych grup wiekowych i do odbiorców o sprecyzowanych zainteresowaniach (ponad 280), choć oczywiście ich zawartość i poziom były bardzo różne. Jest to na pewno ważny temat, który czeka na swojego badacza.

Bogumiła Staniów Instytut Informacji Naukowej i Bibliotekoznawstwa Uniwersytetu Wrocławskiego
Crii elem redaktorów wydanego w serii „Nauka - Dydaktyka - Praktyka” tomu stało się „zaprezentowanie niektórych relacji zachodzących między dyscyplinami, ukazanie płynności granic i wspólnych obszarów badawczych, które stanowią pochodną szerokich zainteresowań naukowych autorów wywodzących się z najważniejszych bibliologicznych ośrodków akademickich kraju”, a „zgromadzone w książce 23 artykuły odzwierciedlają wielość kontekstów współczesnej bibliologii i wskazują na szerokie pole badawcze dyscypliny" (s. 8). Całość składa się z czterech części: Historia i metodologia bibliologii (sześć artykułów), Książka i biblioteka $w$ XX wieku (pięć artykułów), Lodziana (pięć artykułów), Biografistyka księgoznawcza (siedem artykułów). Już sama konstrukcja wydaje się interesująca, ponieważ redaktorzy wydawnictwa starali się ukazać różne aspekty badań bibliologicznych, prowadzonych w różnych ośrodkach naukowych, przez badaczy z poważ-

\section{Oblicza wspótczesnej bibliologii. Konteksty i transgresje, red. nauk. Grzegorz Czapnik, Zbigniew Gruszka, Jacek Ladorucki, tódź: Wydawnictwo Uniwersytetu tódzkiego; Warszawa: Wydawnictwo Stowarzyszenia Bibliotekarzy Polskich 2014, 472 s., ISBN 978-83-7969-372-6}

DOI: http://dx.doi.org/10.12775/TSB.2015.008

nym dorobkiem naukowym oraz tych młodszych, dopiero pracujących na swój wkład w dociekania bibliologiczne. Wśród autorów zamieszczonych w tomie prac przeważają reprezentanci Uniwersytetu Łódzkiego. Poza tą uczelnią reprezentowane są: Uniwersytet Pedagogiczny w Krakowie, Uniwersytet Wrocławski, Uniwersytet Kazimierza Wielkiego w Bydgoszczy, Uniwersytet im. Adama Mickiewicza 
w Poznaniu, Uniwersytet Rzeszowski, Zakład Narodowy im. Ossolińskich (dalej: ZNiO), a także Polska Szkoła Przedmiotów Ojczystych im. św. Józefa w Amersham.

Część pierwszą wydawnictwa rozpoczyna tekst Tomasza Stolarczyka o miejscu historii w bibliologii. Autor wskazał źródła historyczne przechowywane w bibliotekach, służące odtwarzaniu dziejów bibliotek i księgozbiorów. Maria Wichowa zaprezentowała wieloletnie polskie badania nad polonikami ze zbiorów zamku Skokloster w Szwecji. Kolejny, niezbyt obszerny artykuł Krzysztofa Walczaka dotyczy rosyjskich bibliotek publicznych na terenie guberni kaliskiej. Chociaż w podtytule autor uznał, że jest to tylko przyczynek do dziejów bibliotekarstwa początków XX w., to po wstępie i charakterystyce archiwaliów i literatury czytelnik otrzymał wyjątkowo skromne informacje na temat rosyjskiej biblioteki publicznej w Kaliszu i rosyjskiej inicjatywy organizacji bibliotek ludowych. Dalej znajdują się zaskakujące wnioski wypływające jakoby z całego tekstu i opublikowany zupełnie bez komentarza, trzynastostronicowy rosyjsko-polski katalog książek bibliotek publicznych Kraju Nadwiślańskiego z 1898 r. Interesujące i ważne dla dziejów bibliotekarstwa szkolnego źródła opisała Agnieszka Fluda-Krokos. Sprawozdania dyrekcji II Państwowego Gimnazjum i Liceum im. św. Jacka w Krakowie pozwalają „ustalić nie tylko szacunkową wielkość zbiorów, lecz także przedstawić sposoby ich pozyskiwania, fundusze biblioteczne, przepisy, strukturę, zawartość i wykorzystanie". Joanna Stawińska zajęła się drukowanymi katalogami zbiorów rękopiśmiennych przechowywanych w polskich bibliotekach naukowych. Przygotowanie tego tekstu zbiegło się z kolejnym, trzecim już wydaniem pracy Zbiory rękopisów $w$ bibliotekach $i$ muzeach $w$ Polsce opracowanej przez Danutę Kamolową i Teresę Sieniatycką (Warszawa 2014), czego autorka nie mogła już uwzględnić. Aktualnych problemów bibliologii i informatologii dotyczy artykuł Kariny Nabiałczyk. Autorka wskazała powiązania bibliologii i informatologii z innymi dyscyplinami na przykładzie analizy cytowań piśmiennictwa $\mathrm{z}$ lat 1956-2006.

Część drugą prezentowanego tomu zaczyna tekst Ryszarda Nowickiego poświęcony polskim zbiornicom księgozbiorów zabezpieczonych w latach 1947-1955. Autor odtworzył niezwykle ciekawy wątek w dziejach książki i bibliotek. Historii bibliotek dotyczy również artykuł Andrzeja Dróżdża zatytułowany Działalność Centralnego Zarządu Bibliotek (1951-1957). Autor nie dostosował opisów bibliograficznych w przypisach do przyjętych w całym tomie, stąd niektóre $\mathrm{z}$ nich zawierają zbędne elementy lub za- 
skakują (przyp. 41), charakteryzuje je brak konsekwencji, liczne usterki, niezgodny z praktyką naukową sposób opisywania materiałów archiwalnych. Szkoda, że dopiero w drugiej części charakteryzowanego wydawnictwa znalazł się tekst Grzegorza Niecia ukazujący księgarstwo w polskich badaniach nad książką do 1989 r. Autor dokonał interesującego przeglądu publikacji poruszających problematykę księgarską. Danuta Wańka w kolejnym artykule przeanalizowała roczniki „Myśli Narodowej” z lat 1921-1939 pod kątem obecności na jej łamach tematyki dotyczącej książki. Okazało się, że w kręgu zainteresowań redakcji znalazły się: biblioteki, czytelnictwo, wystawy i inne formy popularyzacji książki, bibliografie, bibliofilstwo, ludzie książki oraz reklama książek, druków okolicznościowych i prasy. Na stronie 191 błędnie podano nazwisko autora recenzowanej w „Myśli Narodowej” książki. Był nim Władysław Studnicki, a nie Stadnicki. Z kolei promocją książki w katolickich czasopismach społeczno-kulturalnych pierwszej połowy XX w. w Polsce zajęła się Evelina Kristanova. Artykuł, jak zauważyła sama Kristanova, „stanowi jedynie kompilację wyników badań prowadzonych przez Autorkę w ciągu ostatnich dwunastu lat pod kątem bibliologicznym i podsumowanie dotyczące form promocji książki na łamach czasopism społeczno-kulturalnym o profilu katolickim wydawanych w pierwszej połowie XX wieku. Jego zawartość zatem może nie być zbyt odkrywcza, gdyż niektóre stwierdzenia znane są z poprzednich opracowań" (s. 215-216).

Z całą pewnością można stwierdzić, że bibliolodzy Uniwersytetu Łódzkiego mają poważne osiągnięcia w badaniach nad łódzką książką i prasą, nie mogło więc zabraknąć w opisywanym tomie artykułów poświęconych tym zagadnieniom, zamieszczonych w trzeciej części. Jadwiga Konieczna przedstawiła świat książki Łodzi powojennej, Magdalena Kwiatkowska scharakteryzowała źródła (w spisie treści pracy źródło) do dziejów ruchu wydawniczego w spuściźnie Jana Muszkowskiego przechowywanej w Bibliotece Uniwersytetu Łódzkiego, Monika Sulejewicz-Nowicka przybliżyła postać Andrzeja Kempy jako badacza biografii ludzi książki, Izabela Olejnik ukazała stan badań nad literaturą Zagłady na przykładzie Litzmannstadt Getto, a Martyna Augustyniak zajęła się życiem kulturalnym i naukowym Łodzi na łamach "Dziennika Łódzkiego" z lat 1945-1953.

Ostatnia część prezentowanego to$\mathrm{mu}$, o charakterze biograficznym, zawiera teksty poświęcone wybitnym postaciom świata książki. Adrian Uljasz zajął się znanym i wielokrotnie 
przedstawianym w licznych biografiach bibliotekarzem i bibliologiem Józefem Gryczem. Marta Pękalska pokrótce przybliżyła sylwetki licznych pracowników Zakładu Narodowego im. Ossolińskich, począwszy od fundatora biblioteki Józefa Maksymiliana Ossolińskiego, poprzez kuratorów, dyrektorów, bibliotekarzy i kustoszy, introligatorów, członków Towarzystwa Przyjaciół Ossolineum, pracowników Wydawnictwa ZNiO, drukarzy. Zgodzić należy się $\mathrm{z}$ autorką, że wielu z wymienionych nie doczekało się poświęconych sobie biogramów, nie mówiąc o monografiach. Emilia Klich niezbyt fortunnie zatytułowała swój artykuł Zaangażowanie instytucji nauki i kultury w rozwój polskiej biografistyki księgoznawczej, podczas gdy tekst charakteryzuje zarówno najważniejsze wydawnictwa biograficzne, jak i wybrane instytucje zaangażowane w prace związane z biografistyką księgoznawczą. Wydawnictwo słownikowe „Oficyna bibliofilów” stało się przedmiotem analiz Sabiny Kwiecień. Autorka odnalazła 64 biogramy osób mających wkład w prace na rzecz kultury książki. W kręgu zainteresowań Barbary Góry znaleźli się „Poznańczycy”, wybitni bibliotekarze: Edward Kuntze, Stefan Vrtel-Wierczyński oraz Aleksander Birkenmajer. Autorka, przedstawiając powyższych twórców nowoczesnego bibliotekarstwa, sięgnęła do materia- łów archiwalnych bezpośrednio ich dotyczących, co uatrakcyjniło i uszczegółowiło przekazywane informacje, a dołączone ilustracje źródłowy charakter tekstu dowartościowały. Tekst Elżbiety Pokorzyńskiej dotyczy introligatorów polskich, którzy, zdaniem badaczki, powinni znaleźć się w planowanym „Słowniku introligatorów polskich". Niezbyt obszerny artykuł traktować należy jako wprowadzenie do tematu i zbiór postulatów, ich realizacja pozwoli na przeprowadzenie ambitnego planu. Prezentowany tom zamyka tekst Jacka Ladoruckiego poświęcony Januszowi Duninowi i jego antropologicznemu podejściu do bibliologii.

Najpoważniejszym błędem, jaki odnaleziono w trakcie lektury książki, jest wskazanie Karola Wielkiego jako patron Uniwersytetu Kazimierza Wielkiego w Bydgoszczy (s. 445, 472) oraz brak dbałości o ujednolicenie przypisów w całej pracy.

Czytając Wprowadzenie do wydawnictwa, zgodzić się należy z redaktorami, że „zgromadzone w książce prace odzwierciedlają wieloaspektowość badań prowadzonych w polskich ośrodkach bibliotekoznawczych, wskazują też na liczne koneksje bibliologii z pokrewnymi dyscyplinami”, a „publikacja przyczyni się do wyeksponowania różnorodności współczesnych polskich badań bibliologicznych i stanowić bę- 
dzie inspirację do dalszych poszukiwań naukowych w obrębie szeroko rozumianej kultury książki” (s. 9-10). Redaktorzy przedstawili oblicza współczesnej bibliologii.
Grażyna Gzella

Instytut Informacji Naukowej i Bibliologii Uniwersytetu Mikołaja Kopernika w Toruniu
W ydawać by się mogło, że konspiracyjne tomiki wierszy wydane w czasie II wojny światowej to temat dogłębnie zbadany i opisany. Podczas konferencji naukowych z cyklu „Kraków-Lwów: książki, czasopisma, biblioteki XIX i XX wieku", organizowanych w latach 1999-2013 przez Instytut Informacji Naukowej i Bibliotekoznawstwa Uniwersytetu Pedagogicznego im. KEN w Krakowie, prof. dr hab. Krzysztof Woźniakowski prezentował wyniki swoich dociekań oraz poszukiwań dotyczących głównie Generalnego Gubernatorstwa i ziem włączonych do Rzeszy w okresie okupacji hitlerowskiej 1939-1945. Ich większość została opublikowana w latach 2001-2011. Autor postanowił jednak zebrać je w jednym tomie zatytułowanym Marginalia i obrzeża. Szkice o zapomnianych konspiracyjnych tomikach poetyckich lat 1939-1945. Można dyskutować, czy to dobry pomysł. Praktyka prezentowania w formie książki wcześniej wydanych w różnych latach, rozproszonych w kilku lub kilkunastu miejscach artykułów nie jest nowa. Zabiegi takie spotykamy szczególnie

\section{Krzysztof Woźniakowski, Marginalia i obrzeża. Szkice o zapomnianych konspiracyjnych tomikach poetyckich lat 1939-1945, Opole: Wydawnictwo Naukowe Scriptorium 2013, 224 s., ISBN 978-83-62625-51-2}

DOI: http://dx.doi.org/10.12775/TSB.2015.009

często w okresie dwudziestolecia międzywojennego. Przykładowo tak ukazały się edycje cykli reportaży Konrada Wrzosa pt. Podróż po Polsce dzisiejszej, publikowanych od lutego do kwietnia 1933 r. na łamach krakowskiego „Ilustrowanego Kuriera Codziennego”, a wydane w tym samym roku w wersji książkowej Oko w oko z kryzysem okazały się bestsellerem. Także dziennikarza-odkrywcy Aleksandra Janty-Połczyńskiego „obroty reporterskie” zapisane w tomach: Patrzę na Moskwę i W głąb ZSRR (oba z roku 1933), Made in Japan, Odkrycie Ameryki, wyd. w roku 1935, w o rok starszych repor- 